\section{ELSI-COVID-19 initiative: methodology of the telephone survey on coronavirus in the Brazilian Longitudinal Study of Aging}

\author{
Iniciativa ELSI-COVID-19: metodologia do \\ inquérito telefônico sobre coronavírus entre \\ participantes do Estudo Longitudinal da \\ Saúde dos Idosos Brasileiros
}

\author{
Iniciativa ELSI-COVID-19: metodología para la \\ encuesta telefónica sobre coronavirus en el \\ Estudio Brasileño Longitudinal \\ del Envejecimiento
}

Maria Fernanda Lima-Costa 1,2

James Macinko 3

Fabiola Bof de Andrade 1

Paulo Roberto Borges de Souza Júnior 4

Maurício Teixeira Leite de Vasconcellos 5

Cesar Messias de Oliveira 6

\begin{abstract}
The COVID-19 pandemic (caused by the SARS-CoV-2) is a public health emergency of international concern that particularly affects older people. Brazil is one of the countries most affected by the pandemic, ranking second with the highest number of confirmed cases and deaths worldwide as of mid-June 2020. The ELSI-COVID-19 initiative is based on telephone interviews with participants of the Brazilian Longitudinal Study of Aging (ELSI-Brazil), conducted on a nationally representative sample of the population aged 50 or older. This initiative aims to provide information on adherence to preventive measures (social distancing, wearing masks, and handwashing/hygiene); reasons for leaving the house, when that was the case; difficulties obtaining medications, medical diagnosis of COVID-19, and receipt of confirmatory results; use of health-care services (recent care-seeking, care-seeking location, care receipt, among other aspects); and mental health (sleep, depression, and loneliness). The first round of telephone interviews was conducted between May 26 and June 8, 2020. The second and third rounds are expected to occur within the coming months. This article presents this initiative methodology and some sociodemographic characteristics of the 6,149 participants in the survey first round, relative the Brazilian population within the same age group.
\end{abstract}

COVID-19; Coronavirus; Aged; Health Surveys

\author{
Correspondence \\ M. F. Lima-Costa \\ Núcleo de Estudos em Saúde Pública e Envelhecimento, \\ Instituto René Rachou, Fundação Oswaldo Cruz. \\ Av. Augusto de Lima 1715, 6o andar, sala 614, Belo Horizonte, \\ MG 30190-003, Brasil. \\ lima.costa@fiocruz.br \\ 1 Instituto René Rachou, Fundação Oswaldo Cruz, \\ Belo Horizonte, Brasil. \\ 2 Programa de Pós-graduação em Saúde Púbica, Universidade \\ Federal de Minas Gerais, Belo Horizonte, Brasil. \\ 3 University of California, Los Angeles, U.S.A. \\ 4 Instituto de Comunicação e Informação Científica e \\ Tecnológica em Saúde, Fundação Oswaldo Cruz, Rio de Janeiro, \\ Brasil. \\ 5 Escola Nacional de Ciências Estatísticas, Fundação Instituto \\ Brasileiro de Geografia e Estatística, Rio de Janeiro, Brasil. \\ 6 University College London, London, U.K.
}




\section{Introduction}

The COVID-19 pandemic, caused by the SARS-CoV-2 virus, is a public health emergency of international concern that poses more questions than answers. Community transmission was officially recognized in Brazil on March 20 2020; since then, the number of new cases and deaths have significantly risen and exponentially progressed, without signs that the pandemic is getting under control 1. The virus spread so rapidly that, by June 9, 2020, Brazil ranked second with the highest number of confirmed cases $(707,412)$ and deaths $(52,771)$ worldwide (Johns Hopkins University \& Medicine. COVID-19 Dashboard by the Center for Systems Science and Engineering (CSSE) at Johns Hopkins University. https://coronavirus.jhu.edu/map.html, accessed on 09/Jun/2020).

Older adults and those with pre-existing chronic conditions are more severely affected by COVID-19 1 (https://coronavirus.jhu.edu/map.html, accessed on 09/Jun/2020). Despite age-related biological factors, health behaviors, socioeconomic, and environmental factors also appear to maximize the pandemic determinants and consequences in older age groups. These factors could impact population directly, by increasing the risk of infection or individual susceptibility to SARS-CoV-2, or indirectly, by worsening pre-existing chronic conditions or increasing the risk of new diseases. Regarding socio-environmental factors, a large proportion of the Brazilian population is affected by poor housing conditions, inadequate sanitation, and high household occupancy rates, increasing even further susceptibility and transmission rates 2 .

Some factors could directly or indirectly impact epidemic-related risks among older Brazilian adults, such as: (1) chronic conditions requiring regular monitoring and medications 3,4,5; (2) worse physical functioning requiring help to perform activities as purchasing basic items, such as food and medicine, or even survival-related activities, such as feeding, dressing, and bathing 6,7,8; and (3) difficulties using new technology that allows online communication with family and friends, which could possibly improve mental health by reducing loneliness, sleep disorders, and depression 9,10 . The inability to access regular health-care services or medications during the epidemic is yet another factor that could aggravate pre-existing physical and mental conditions 11 .

The Brazilian Longitudinal Study of Aging (ELSI-Brazil) is a household-based cohort study that aims to investigate ageing in Brazil and its determinants and consequences for individuals and society 8 . ELSI-Brazil sample is composed of older adults, which represents an opportunity to collect data on the SARS-CoV-2 epidemic and its effects on the older population, given the current public health emergency scenario. Considering that, we developed the ELSI-COVID-19 telephone interview initiative. This article aims to briefly describe this initiative methodology and examine its external validity regarding sociodemographic characteristics.

\section{Methods}

\section{Study design}

ELSI-Brazil is a nationally representative population-based cohort study composed of non-institutionalized community-dwelling Brazilians aged 50 years and older. The study used a probability complex sampling clustered in strata, combining municipalities, census tracts, and households. The final sample included 70 municipalities in all five major geographic regions of the country. After baseline, data will be collected every 3 to 4 years with refreshment sample in each wave 8 .

ELSI-Brazil baseline survey was conducted from 2015 to 2016, and the final sample comprised 9,412 participants aged 50 and older. Baseline measurements included: household interview (household characteristics and residents economic conditions); individual interview (demographic characteristics, health and health-related conditions, use of health-care services, among others); physical measurements (anthropometry, blood pressure, and physical functioning); and blood tests, with samples storage in a sub-sample. Further details on ELSI-Brazil survey methodology are described elsewhere ${ }^{8}$. Questionnaires and other research instruments can be found on ELSI-Brazil homepage (http://elsi.cpqrr.fiocruz.br/). 
ELSI-Brazil second wave started in August 2019 but was interrupted on March 17 due to the SARS-CoV-2 pandemic. As ELSI-Brazil sample is comprised of older people, in-person data collection was suspended by ethical considerations, to avoid potential virus transmission during household visit. Until its interruption, 9,177 participants were interviewed and had their physical measurements assessed, following the same research instruments and procedures adopted at baseline.

\section{COVID-19 telephone interview}

All individuals who participated in the second wave were eligible for telephone interview. The interview was designed to be short, lasting about five minutes, and addressed questions on adherence to preventive measures (social distancing, wearing masks, and handwashing/hygiene), reasons for leaving the house, difficulties obtaining medications, medical diagnosis for COVID-19, and testing, use of health-care services (recent care-seeking, where care was sought and whether it was received, among other aspects), and mental health (sleep, depression, and loneliness).

A digital version of the questionnaire was designed and, as information was collected by phone interviews, data were transmitted in real time using data encryption protocols. Trained interviewers performed the telephone calls - mostly the same who conducted second-wave household interviews - directly with the main study participant. If necessary, someone other than the main participant was allowed to complete the survey. We deemed as refusal interviews in which participants refused to participate in the first telephone call, or when five telephone calls attempts at different times and days were unanswered. Quality control was ensured by telephone callbacks using a subsample. A letter or text message was sent to all eligible respondents before telephone interview to increase response rate. A toll-free number and an explanation on the main ELSI-Brazil homepage (http://elsi.cpqrr.fiocruz. $\mathrm{br} /$ ) were used to provide further details to participants. The first round of telephone interviews was conducted between May 26 and June 8, 2020. Two follow-up interviews are planned for the subsequent eight and sixteen weeks.

ELSI-Brazil and the ELSI-COVID-19 initiative were approved by the Ethics Committee of the Fiocruz, Minas Gerais (protocol n. 34649814.3.0000.5091 and CAAE: 33492820.3.0000.5091).

\section{Statistical analysis}

As ELSI-Brazil has a complex sampling design, analyses must consider the design and include individuals' weights within the sample. Survey weights for analyzing telephone interview data were specifically calculated for participants who answered the survey, considering their age, gender, and education level. Mean natural (based on sampling design) and calibrated weights were: 5.428,7 (standard error $-\mathrm{SE}=82.7)$ and 8.783,7 $(\mathrm{SE}=179.1)$ for the first stratum; 6.071,7 $(\mathrm{SE}=138.0)$ and 9.597,0 $(\mathrm{SE}=228.3)$ for the second; 7.845,7 $(\mathrm{SE}=203.4)$ and $11.492,0(\mathrm{SE}=352.0)$ for the third; and 4.345,1 $(\mathrm{SE}=63.9)$ and $6.747,9(\mathrm{SE}=126.2)$ for the fourth.

To assess representativeness of the telephone interview sample, the sociodemographic characteristics of our study participants were compared to those aged 50 and older who participated in the Continuous Brasilian National Household Sample Survey (PNAD Continuous), conducted by the Brazilian Institute of Geography and Statistics (IBGE) in the last quarter of 2019 with a nationally representative sample of Brazilian adults 12 .

\section{Results}

Of the 9,177 eligible ELSI-Brazil participants, 6,149 (67\%) participated in the telephone survey. Losses were due to deaths $(n=120)$, hospitalizations or institutionalization $(n=6)$, refusal to provide information via telephone $(n=109)$, unanswered calls after five attempts $(n=913)$ and invalid or missing telephone number $(n=1,880)$. Figure 1 shows the map of Brazil with the distribution of the included municipalities by state and geographical regions. 


\section{Figure 1}

Map of Brazil showing municipalities participating in the telephone survey, Brazilian Longitudinal Study of Aging COVID-19 (ELSI-COVID-19), May-June, 2020.

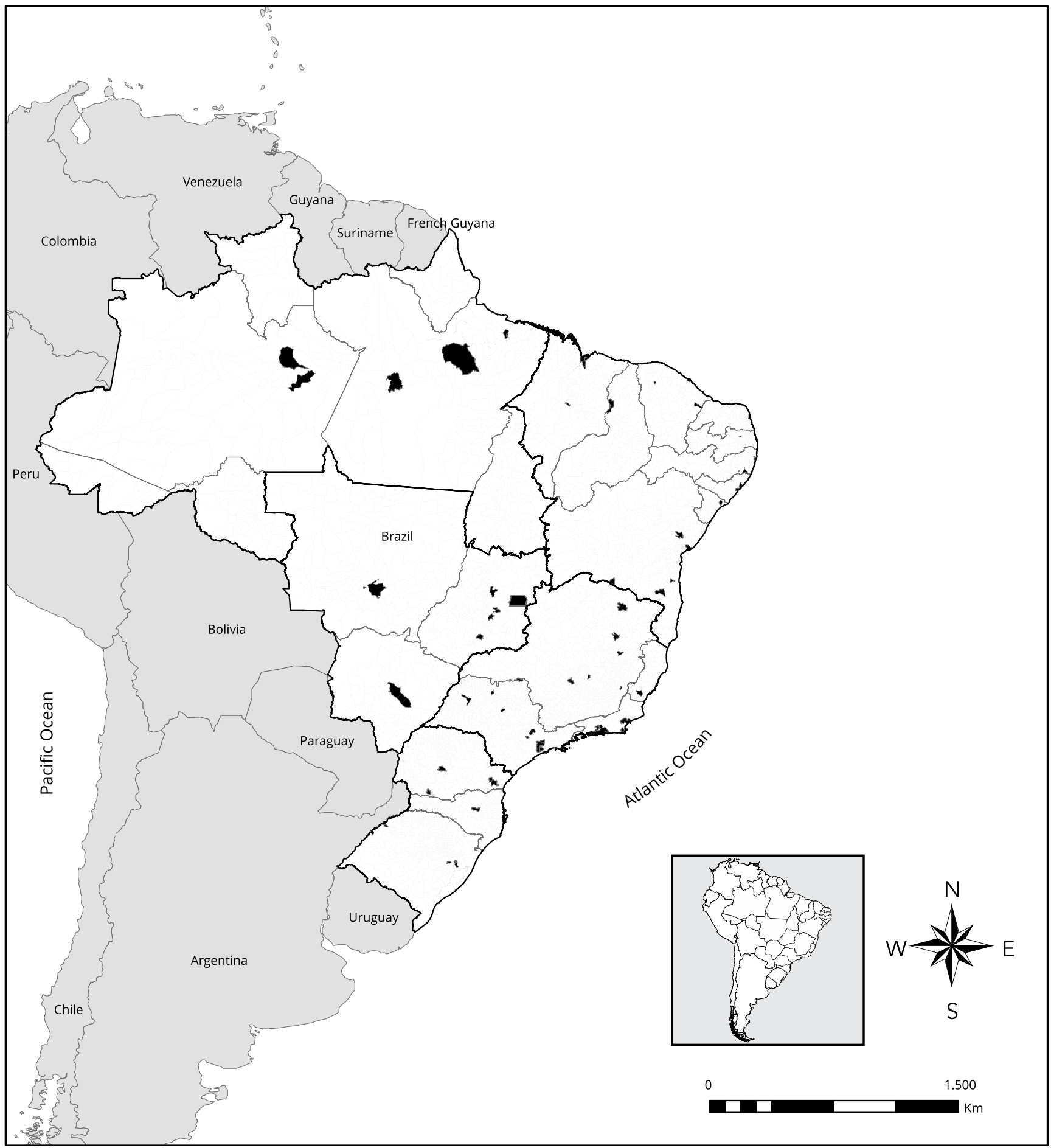


Participants' mean age was 63.3 years and $54.4 \%$ of them were women (Table 1). The average number of residents per household was 2.42 people, $12.6 \%$ of participants resided in rural areas, and $6.3 \%$ were from the north region and $41.5 \%$ from the southeast. Over a quarter $(27.6 \%)$ had four years of education or less, whereas $33.8 \%$ completed 12 or more year; $45.3 \%$ classified themselves as white and $9.7 \%$ as black. Overall, these characteristics were nearly identical to those reported by the PNAD Continuous.

\section{Discussion}

The ELSI-COVID-19 initiative is associated with a population-based cohort to provide a better understanding on the determinants and consequences of the SARS-CoV-2 pandemic among older Brazilian adults. A great advantage of this initiative is the opportunity to use a wide range of information collected among cohort participants before the beginning of the pandemic, enabling us to compare them with data collected during and after the pandemic. It also comprises a large number of participants residing in different municipalities from all major geographical regions in Brazil.

The limitations of this study are those inherent to any research conducted using telephone interviews: unanswered calls, refusal in providing certain information by phone, and invalid phone numbers for some respondents, as we observed in our study. Our final response rate was $67 \%$ - slightly higher than that reported by another recent nationally-representative telephone interview $(60.2 \%)$

Table 1

\begin{tabular}{|c|c|c|c|c|}
\hline \multirow[t]{2}{*}{ Characteristics } & \multicolumn{2}{|c|}{ ELSI-COVID-19 (n = 6,149) } & \multicolumn{2}{|c|}{ PNAD ( $n=155,041)$} \\
\hline & Mean or \% & $95 \% \mathrm{Cl}$ & Mean or \% & $95 \% \mathrm{Cl}$ \\
\hline Mean age (years) & 63.3 & $62.4-64.1$ & 63.2 & $63.1-63.3$ \\
\hline Women (\%) & 54.4 & $51.9-56.9$ & 55.0 & $54.8-55.2$ \\
\hline $\begin{array}{l}\text { Mean number of residents per } \\
\text { household }\end{array}$ & 2.4 & $2.3-2.5$ & 2.8 & $2.8-2.9$ \\
\hline Rural area (\%) & 12.6 & $9.5-15.8$ & 13.6 & $13.3-13.9$ \\
\hline \multicolumn{5}{|l|}{ Major geographical regions (\%) } \\
\hline North & 6.3 & $0.2-12.5$ & 6.3 & $6.1-6.5$ \\
\hline Northeast & 27.0 & $18.3-35.7$ & 25.1 & $24.7-25.5$ \\
\hline Southeast & 40.5 & 29.7-51.2 & 45.8 & $45.3-46.3$ \\
\hline South & 16.0 & $7.0-25.0$ & 15.8 & $15.6-16.1$ \\
\hline Central & 10.2 & $4.1-16.2$ & 7.0 & $6.8-7.2$ \\
\hline \multicolumn{5}{|l|}{ Years of education (\%) } \\
\hline Up to 4 & 27.8 & $25.0-30.6$ & 27.8 & $27.4-28.3$ \\
\hline $5-8$ & 27.8 & $25.7-30.0$ & 27.8 & $27.5-28.2$ \\
\hline $9-11$ & 10.6 & $9.6-11.6$ & 10.6 & $10.3-10.8$ \\
\hline 12 or more & 33.8 & $30.1-37.4$ & 33.8 & $33.2-34.3$ \\
\hline \multicolumn{5}{|l|}{ Race/skin color (\%) } \\
\hline White & 52.3 & $46.1-58.5$ & 47.7 & $47.1-48.2$ \\
\hline Black & 9.7 & $7.5-11.9$ & 9.6 & $9.3-9.8$ \\
\hline Brown & 37.0 & $31.4-42.6$ & 41.6 & $41.1-42.0$ \\
\hline Yellow/indigenous & 0.1 & $0.4-1.5$ & 1.2 & $1.1-1.3$ \\
\hline
\end{tabular}

95\% Cl: 95\% confidence intervals.

Note: all results are weighted by sampling design and individual weights for each survey. 
conducted by the Brazilian Institute of Geography and Statistics (IBGE) 13. To compensate for nonresponse, we adopted weights derived specifically for telephone surveys that consider participants' gender, age, and education level. After applying these weights and other sample parameters, our study population distribution resembles that of the Brazilian population obtained by a face-to-face household survey conducted in the 4 th quarter of 2019. However, we cannot discard potential bias from other unmeasured factors.

We believe the ELSI-COVID-19 initiative have great potential. Two other rounds of telephone interviews are planned for the upcoming months, allowing us to investigate changes in preventive behaviors and other SARS-CoV-2 related aspects during the evolution of the pandemic. The thirdwave ELSI-Brazil cohort is expected to be conducted three years from now (2023) by individual and household interviews, and will again collect physical measurements and blood samples. This would allow us to investigate long-term consequences of the pandemic in older adults and estimate the prevalence of SARS-CoV-2 infection within our sample.

ELSI-Brazil employs the same conceptual framework and research instruments as other large population-based longitudinal ageing studies worldwide 8, one of which is the English Longitudinal Study of Ageing 14. Recently, this study initiated a COVID-19 online survey, and other ageing studies in the network are expected to follow the same initiative. This will allow us to compare Brazilian data with other countries experiences.

We still do not know how the SARS-CoV-2 pandemic will evolve in different social and economic contexts. Successive waves of the infection may occur until an effective vaccine is developed, so evidence-based scientific information is crucial to guide preventive measures and mitigate the impact of COVID-19 on the population. In an unequal nation like Brazil, the ELSI-COVID-19 initiative will contribute to a better understanding of the pattern and determinants of the pandemic in older adults in a context of great social inequalities.

\section{Contributors}

M. F. Lima-Costa drafted the first version of the manuscript. All authors equally contributed with the writing and revision of the final version of the manuscript.

\section{Additional informations}

ORCID: Maria Fernanda Lima-Costa (0000-00023474-2980); James Macinko (0000-0001-80555441); Fabiola Bof de Andrade (0000-0002-34673989); Paulo Roberto Borges de Souza Júnior (00000002-8142-4790); Maurício Teixeira Leite Vasconcellos (0000-0003-1658-2589); Cesar Messias de Oliveira (0000-0002-4099-4762).

\section{Acknowledgments}

The ELSI-Brazil baseline and the second wave were supported by DECIT/SCTIE (grant 404965/20121 and 28/2017)); COSAPI/DAPES/SAS (grants 20836, 22566, 23700 and 77/2019). The ELSI-COVID-19 is funded by the DECIT/SCTIE and the Brazilian National Research Council - CNPq (grant n. 403473/2020-9). Maria Fernanda LimaCosta is a fellow of the CNPq.

\section{References}

1. Ministério da Saúde. Ministério da Saúde. Boletim Epidemiológico Especial, 17. https://www.saude.gov.br/images/pdf/2020/ May/29/2020-05-25---BEE17---Boletim-doCOE.pdf (accessed on 25/May/2020).

2. Werneck GL, Carvalho MS. The COVID-19 pandemic in Brazil: chronicle of a health crisis foretold. Cad Saúde Pública 2020; 36:e00068820.

3. Nunes BP, Batista SRR, Andrade FB, Souza Júnior PRB, Lima-Costa MF, Facchini L. Multimorbidity: the Brazilian Longitudinal Study of Aging (ELSI-Brazil). Rev Saúde Pública 2018; 52 Suppl 2:10s.

4. Firmo JOA, Mambrini JVM, Peixoto SV, Loyola Filho AI, Souza Júnior PRB, Andrade $\mathrm{FB}$, et al. Adequate control of hypertension among older adults: ELSI-Brazil. Rev Saúde Pública 2018; 52 Suppl 2:13s.

5. Loyola Filho AI, Firmo JOA, Mambrini JVM, Peixoto SV, Souza Jr. PRB, Andrade FB, et al. Cost-related underuse of medications in older adults: ELSI-Brazil. Rev Saúde Pública 2018; 52 Suppl 2:8s. 
6. Andrade FB, Duarte YAOD, Souza Júnior PRB, Torres JL, Lima-Costa MF, Andrade FCD. Inequalities in basic activities of daily living among older adults: ELSI-Brazil, 2015. Rev Saúde Pública 2018; 52 Suppl 2:14s.

7. Giacomin KC, Duarte YAO, Camarano AA, Nunes DPN, Fernandes D. Care and functional disabilities in daily activities - ELSI-Brazil. Rev Saúde Pública 2018; 52 Suppl 2:9s.

8. Lima-Costa MF, Andrade FB, Souza Jr. PRB, Neri AL, Duarte YAO, Castro-Costa E, et al. The Brazilian Longitudinal Study of Aging (ELSI-BRAZIL): objectives and design. Am J Epidemiol 2018; 187:1345-53.

9. Neri AL, Borim FSA, Fontes AP, Rabello DF, Cachioni M, Batistoni SST, Yassuda MS, Souza Júnior PRB, Andrade FB, Lima-Costa MF Factors associated with perceived quality of life in older adults: ELSI-Brazil. Rev Saúde Pública 2018; 52 Suppl 2:16s.

10. Armitage R, Nellums LB. COVID-19 and the consequences of isolating the elderly. Lancet Public Health 2020; 5:e256.
11. Macinko J, Andrade FB, Souza Júnior PRB, Lima-Costa MF. Primary care and healthcare utilization among older Brazilians (ELSI-Brazil). Rev Saúde Pública 2018; 52 Suppl 2:6s.

12. Instituto Brasileiro de Geografia e Estatística. Pesquisa Nacional por Amostra de Domicílios contínua quartotrimestre de 2019. https:// biblioteca.ibge.gov.br/visualizacao/periodi cos/2421/pnact_2019_4tri.pdf (accessed on 22/Jun/2020)

13. Instituto Brasileiro de Geografia e Estatística. Pesquisa Nacional por Amostra de Domicílios contínua. Nota técnica - informações referentes à coleta do mês de abril de 2020. Rio de Janeiro: Instituto Brasileiro de Geografia e Estatística; 2020.

14. English Longitudinal Study of Ageing: ELSA Covid-19 study launched. https://www. elsa-project.ac.uk/post/elsa-covid-19-studylaunched (accessed on 22/Jun/2020). 


\section{Resumo}

A pandemia COVID-19 (causada pelo SARS- CoV-2) é uma emergência global de saúde pública, que afeta principalmente os mais velhos. $O$ Brasil é um dos países mais impactados pela pandemia, ocupando o segundo lugar no mundo em número de casos confirmados e mortes em meados de junho de 2020. A iniciativa ELSI-COVID-19 é baseada em entrevistas telefônicas com participantes do Estudo Longitudinal da Saúde dos Idosos Brasileiros (ELSI-Brasil), realizado em amostra nacionalmente representativa da população com 50 anos ou mais. Os principais objetivos dessa iniciativa são produzir informação sobre a adesão às medidas preventivas (distanciamento social, uso de máscara facial e lavagem das mãos/ higiene), motivos para sair de casa quando foi o caso, dificuldades na obtenção de medicamentos, diagnóstico médico de COVID-19 e recebimento de exames confirmatórios, utilização de serviços de saúde (procura recente por atendimento, local da procura e recebimento da atenção, entre outros aspectos) e saúde mental (sono, depressão e solidão). A primeira rodada de entrevistas por telefone foi realizada entre 26 de maio e 8 de junho de 2020. A segunda e a terceira rodadas de entrevistas estão planejadas para ocorrer nos próximos meses. Aqui, apresentamos a metodologia dessa iniciativa e algumas características sociodemográficas dos 6.149 participantes da primeira rodada da pesquisa em relação à população brasileira da mesma faixa etária.

COVID-19; Coronavírus; Idoso; Inquéritos Epidemiológicos

\section{Resumen}

La pandemia de COVID-19, causada por el SARS-CoV-2, es una emergencia pública global, que particularmente afecta a las personas mayores. Brasil es uno de los países más perjudicados por la pandemia, ocupando el segundo puesto en el mundo, en cuanto al número de casos confirmados y muertes hasta mediados de junio 2020. La iniciativa ELSI-COVID-19 está basada en entrevistas telefónicas de participantes en el Estudio Brasileño Longitudinal del Envejecimiento (ELSI-Brasil), realizado en una muestra nacional representativa de población con 50 años o más. Los objetivos principales de esta iniciativa son: producir información sobre la adherencia a las medidas preventivas (distanciemento social, llevar máscarillas faciales, y lavado de manos/higiene); así como las razones, cuando fuera el caso, para dejar el hogar, dificultades para conseguir medicación, diagnóstico médico de COVID-19y recepción de test confirmatorios, uso de servicios de salud (búsqueda de cuidado recientemente, localización de la búsqueda de cuidado y recepción del mismo, entre otros aspectos); al igual que sobre salud mental (sueño, depresión y soledad). La primera ronda de entrevistas por teléfono se realizó entre el 26 de mayo y el 8 de junio de 2020. La segunda y tercera ronda de entrevistas se planificaron para que tuvieran lugar en los meses posteriores. Aquí, presentamos la metodología de esta iniciativa y algunas características sociodemográficas de los 6.149 participantes en la primera ronda de la encuesta, respecto a quienes dentro de la población brasileña estaban en el mismo rango de edad.

COVID-19; Coronavirus; Anciano; Encuestas Epidemiológicas
Submitted on 25/Jun/2020

Final version resubmitted on 05/Aug/2020

Approved on 07/Aug/2020 